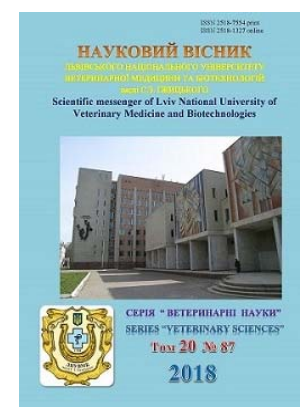

\author{
Науковий вісник Дьвівського національного університету \\ ветеринарної медицини та біотехнологій імені С.З. Гжицького
}

\author{
Scientific Messenger of Lviv National University \\ of Veterinary Medicine and Biotechnologies
}

UDC 616:615 (477)

\title{
Use of fluoroquinolones in practice of veterinary medicine of Ukraine
}

\author{
N. Slobodyuk \\ Stepan Gzhytskyi National University of Veterinary Medicine and Biotechnologies Lviv, Ukraine
}

Article info

Received 19.02.2018

Received in revised form 22.03.2018

Accepted 26.03.2018

Stepan Gzhytskyi National University of Veterinary Medicine and Biotechnologies Lviv, Pekarska str., 50, Lviv, 79010, Ukraine.

Tel.: +38-067-706-44-48 E-mail: slobodjuknm@gmail.com
Slobodyuk, N. (2018). Use of fluoroquinolones in practice of veterinary medicine of Ukraine. Scientific Messenger of Lviv National University of Veterinary Medicine and Biotechnologies. 20(87), 89-93. doi: 10.15421/nvlvet8718

Antibacterial agents are one of the most important groups of medical preparations in the treatment of bacterial infection of different localization in humane and in veterinary medicine. The consequence of their rational use (the establishment of sensitivity of the pathogenic microflora, compliance with the course of treatment, etc.) have a high therapeutic effect and the minimum development of resistant strains of microorganisms. The widely used group of antimicrobial agents in veterinary medicine are second-generation fluorohinolone antibiotics that have good pharmacokinetic properties, a broad spectrum of bactericidal activity, and relatively low toxicity, although they have their own warnings and restrictions on the use of small animals during the formation of bone tissue. To achieve high therapeutic efficacy and minimizing of side effects, it is described the compatibility of some fluoroquinolones with other pharmacological groups. They found their application in the treatment of both productive animals, poultry, fur animals and petty domestic (dogs and cats) with a bacterial infection of the urinary tract, digestive and respiratory systems, infected wounds, etc. The article describes the detailed mechanism of action of the antibiotics of the fluoroquinolone group, which provides an opportunity for a deeper understanding of the manifestation of the bactericidal effect, as well as their classification by generation or generation. Particular attention deserves attention to the time of carrenia of fluoroquinolones in the context of their application to productive animals, because high quality livestock products minimize the development of resistant strains in humans and provide them with health. There is also a list of all registered medicinal products registered in Ukraine containing: ofloxacin, enrofloxacin, ciprofloxacin, marbofloxacin, denofloxacin, which carries important informative information for practicing doctors, pharmacists, etc.

Key words: fluoroquinolones, antibacterial agents, mechanism of action, bactericidal effect, generation, carencia, productive animals.

\section{Застосування флуорхінолонів у практиці ветеринарної медицини України}

\author{
Н.М. Слободюк
}

Львівський національний університет ветеринарної медицини та біотехнологій імені С.3. Гжсицького, м. Львів, Україна

\footnotetext{
Антибактеріальні засоби є однією із найважливіших груп лікарських препаратів при лікуванні бактеріальної інфекиї̈ різної локалізації як у гуманній, так і у ветеринарній медицині. Наслідком ї раціонального застосування (встановлення чутливості патогенної мікрофлори, дотримання курсу лікування тощо) є високий терапевтичний ефект і мінімальний розвиток резистентних итамів мікроорганізмів. Широковживаною групою протимікробних засобів у ветеринарній медицині є антибіотики флуорхінолону другої генерачії, що володіють добрими фармакокінетичними властивостями, широким спектром бактерицидної дії, відносно низькою токсичністю, хоча й мають свої застереження та обмеження у застосуванні дрібним тваринам в період формування кісткової тканини, тваринам із важкими порушеннями функиій печінки та нирок. Для досягнення високої терапевтичної ефективності й мінімізаџї побічних ефектів, описано сумісність деяких флуорхінолонів з лікарськими препаратами інших фармакологічних груп. Вони знайшли своє застосування у лікуванні як продуктивних тварин, птиці, пушних звірів $і$ дрібних домашніх (собак $i$ котів) із бактеріальною інфекиією сечовидільної, травної й дихальної систем, інфікованих ран тощо. У статті описано детальний механізм дї антибіотиків групи флуорхінолону, що дає можливість глибшого розуміння прояву бактерицидного ефекту, а також їх класифікацію за поколіннями чи генераџією. На особливу увагу заслуговує питання часу каренції флуорхінолонів в кон-
} 
тексті застосування їх продуктивним тваринам, оскільки високоякісна тваринницька продукція мінімізує розвиток резистентним штамів у людей та забезпечує їм здоров'я. Також подано перелік усіх зареєстрованих в Україні лікарських препаратів, які містять: офлоксачин, енрофлоксачин, ичпрофлоксацин, марбофлоксацин, данофлоксачин, що несе важливу інформативність для практикуючих лікарів, керівників аптек тощзо.

Ключові слова: флуорхінолони, антибактеріальні засоби, механізм дї, бактерицидний ефект, генерація, каренція, продуктивні тварин.

\section{Вступ}

Флуорхінолони - протимікробні засоби із унікальним механізмом бактерицидної дії зарекомендували себе як високоефективні лікарські препарати для лікування як продуктивних, так і не продуктивних тварин з інфекціями різної етіології в Україні. Першими були синтезовані у 1962 році нефлуровані хінолони (Albrecht, 1977; Walker and Wright, 1991; Asahiu and Ishizak, 1992; Cross, 2001), котрі через обмежений спектр протимікробної дії, невисоку біодоступність, слабке проникнення в органи та тканини організму, обмежені показання щодо застосування й шляхи введення не знайшли широкого використання у практиці ветеринарної медицини. Змінивши структуру хінолону, а саме увівши в його молекулу атом флуору в положенні 6 циклу гетероциклічної системи, були синтезовані та запропоновані для клінічної практики у 1978 році препарати під загальною назвою фторхінолони (фторовані хіноліни), чи 6 - фтор - 4 - хінолон - 3 - карбонова кислота (Padejskaja and Jakovlev, 1995).

Усі хінолони поділяють на чотири генерації. До першої відносяться нефлуровані хінолони, а саме: налідиксова, оксолінова та піпемідова кислоти. До другої генерації відносяться флуровані хінолони, серед яких $є$ : ципрофлоксацин, норфлоксацин, пефлоксацин, офлоксацин, енрофлоксацин, марбофлоксацин, данофлоксацин, діфлоксацин, сарафлоксацин, орбіфлоксацин. До хінолінів третьої генерації відноситься: левофлоксацин, пазуфлоксацин, спарфлоксацин, балофлоксацин. Геміфлоксацин, моксифлоксацин, прадофлоксацин становлять групу флуорохінолонів четвертої генерації (Beco et al., 2013; Maslanka, 2014).

Флуровані хінолони володіють широким спектром протимікробної дії, оптимальними фармакокінетичними властивостями, широкими показами щодо застосування, відносно низькою токсичністю (Lode et al., 1989; Lode et al., 1990; Bush et al., 1993; Swarz, 1997; Kosenko et al., 2000; Slobodiuk, 2003; Khmelnytskyi and Dukhnytskyi, 2017), а швидкий бактерицидний ефект досягається за рахунок їх механізму дії, котрий став відомий у 1974 році. Було детально вивчено будову бактеріальної клітини та усі процеси укладання ДНК в хромосомі, що дало можливість розуміння механізму дії флуорхінолонів. Великим досягненням науки стало відкриття будови ферменту ДНК-гірази, що відповідає за нормальну укладку ДНК в хромосомі бактеріальної клітини (Smith, 1986; Piddock et al., 1990; Fadeeva et al., 1993; Brighty and Gootz, 2000). Встановлено, що ДНК-гіраза - це тетраметр, котрий складається із чотирьох субодиниць, з яких 2 субодиниці А (молекулярною масою 105000 дальтон) і 2 субодиниці В (молекулярною масою 95000 дальтон), кожна 3 яких виконує свою функцію чи роль, а саме: одна із субодиниць А каталізує процес розриву нитки двоспіральної ДНК 3 утворенням двох вільних кінців, а субодиниця В відповідає за процес додаткового скручування ниток ДНК (суперскручування чи негативна суперспіралізація), що відбувається в присутності йонів магнію та енергії, якою $є$ гідроліз аденозинтрифосфорної кислоти. Після цих двох етапів знову в процес вступає друга субодиниця А, котра зшиває і закінчує процес формування повноцінної двоспіральної ДНК. Яке ж місце флуорхінолону у цьому процесі? Як було встановлено, гідрофільні сполуки проникають через зовнішню мембрану пуриновими каналами, а ліпофільні - через ліпополісахаридний шар. За рахунок високої чутливості ферменту ДНК-гірази до флуорхінолонів останні інгібують функцію ферменту (тому ще й мають назву інгібітори ДНК-гірази), а саме: антибіотик прямує у місце створення комплексу ДНК+субодиниця А, результатом чого є утворення нового комплексу ДНК+субодиниця А+флуорхінолон. Надалі не відбувається процес суперспіралізації 3 утворенням повноцінної ДНК (Padejskaja and Jakovlev, 1995; Bogomolov, 1995).

Високочутливими до флуорхінолонів є більшість штамів грампозитивних аеробних бактерій (Staphylococcus spp.), більшість штамів грамнегативних, у тому числі E. coli (включаючи ентеротоксигенні штами), Shigellaspp., Salmonella spp., Enterobacter spp., Klebsiella spp., Proteus spp., Serratia spp., Providencia spp., Citrobacter spp., M.morganii, Vibrio spp., Haemophilus spp., Neisseria spp., Pasteurella spp., Pseudomonas spp., Legionella spp., Brucella spp., Listeria spp (Blatun et al., 1994; Padejskaja and Jakovlev, 1995; Padejskaja and Jakovlev, 1996).

На ринку України зареєстровані й офіційно можуть використовуватися найрізноманітніші антибактеріальні препарати з групи флуорхінолону як вітчизняних, так і зарубіжних виробників. Усі вони відносяться до критично важливих протимікробних засобів першого, другого та третього поколінь. Серед діючих речовин синтезовані й широко використовуються: офлоксацин, норфлоксацин, ципрофлоксацин, енрофлоксацин, марбофлоксацин (Kotsiumbas, 2017).

До лікарських препаратів, що містять офлоксацин, відносяться: «Офлоксацинвет 10\%» у формі ін'єкційного розчину та розчину для перорального застосування (ТОВ «Ветсинтез», Україна). Обидва препарати використовують для лікування собак і котів із: сепсисом, артритом, поліартритом, менінгітом, маститом, дерматитом, тонзилітом, трахеїтом, пневмонією, бронхітом, ринітом, синуситом, бронхопневмонією, гастритом, ентеритом, перитонітом, нефритом, пієлітом, пієлонефритом, уретритом, метритом, уроциститом. Серед застережливих заходів відміча- 
ють те, що вищевказані препарати не рекомендують застосовувати котам до 8-місячного віку та собакам в період формування хрящової та кісткової тканин, а саме: собакам великих порід до 18-місячного віку, собакам дрібних порід - до 8-місячного. Одночасно офлоксацин не можна застосовувати 3 макролідами, лінкозамідами, циклоспоринами, тетрациклінами, хлорамфеніколом і з нестероїдними протизапальними засобами. Не застосовувати вагітним тваринам та 3 порушенням функції нирок та печінки.

«Норфлоквет 20\%» та «Норфлоксацин 10\%» (відповідно ТОВ «Ветсинтез», Україна та ПФО «ВЕТОСФАРМА», Польща) - розчини для перорального застосування із діючою речовиною норфлоксацин. «Норфлоквет 20\%» використовується для лікування дрібних тварин (собак і котів) із: сепсисом, артритом, поліартритом, менінгітом, маститом, дерматитом, тонзилітом, трахеїтом, пневмонією, бронхітом, ринітом, синуситом, бронхопневмонією, гастритом, ентеритом, перитонітом, нефритом, пієлітом, пієлонефритом, уретритом, метритом, уроциститом. «Норфлоксацин 10\%» рекомендують для лікування голубів при захворюваннях травного каналу та органів дихання, що спричинені мікроорганізмами, чутливими до норфлоксацину. Серед протипоказань відмічають несумісність норфлоксацину з макролідами, лінкозамідами, циклоспоринами, тетрациклінами, хлорамфеніколом й з нестероїдними протизапальними засобами. Не рекомендують вагітним тваринам та з порушенням роботи печінки та нирок.

Із діючою речовиною ципрофлоксацин відомі декілька препаратів різних виробників й застосування. Зокрема, «Ципровет 10\%» (Аль-Фаіхаа фо Ветериінаpi Індастріс, Сирійська республіка) використовують для лікування собак, котів і голубів із колібактеріозом, стрептококозом, пастерельозом, хронічними респіраторними захворюваннями й патологіями травного каналу. Щодо застережливих заходів у використанні дрібним тваринам й сумісності 3 препаратами різних груп, вони такі ж, як і у офлоксацину. «Ципрофлоквет $10 \%$ - розчин для перорального застосування (ТОВ «Ветсинтез», Україна), який застосовують для лікування дрібних тварин при захворюваннях органів дихання (трахеїт, тонзиліт, пневмонія, бронхіт, риніт, синусит, бронхопневмонія), травного каналу (гастрит, ентерит, перитоніт), сечостатевої системи (нефрит, пієліт, пієлонефрит, уретрит, уроцистит, метрит), септичних явищах, поліартриті, артриті, менінгіті, дерматиті. У зв'язку із нейротоксичним ефектом препарат не може бути рекомендований вагітним тваринам, а також із порушенням функціонального стану нирок та печінки. Щодо сумісності з іншими групами препартатів, то вони такі ж, як і у офлоксацину й норфлоксацину.

Енрофлоксацин у різних лікарських формах знайшов своє застосування як для лікування непродуктивних, так і продуктивних тварин. «Авітрил-10» (Авіко ветеринарі фармацевтікалс фекторі, Сирійська республіка. Араб ветеринарі індастріал компані (Авіко), Йорданія) - ін'єкційний розчин для лікування собак і котів із патологією органів травної, дихальної та сечостатевої систем, шкіри та зовнішнього слухового проходу, ранових інфекціях; кролям застосовують при захворюваннях травного каналу та органів дихання; ВРХ, вівцям, козам, свиням - за септицемії, маститу, діареї, сальмонельозу, дизентерії, бронхопневмонії, гнійних ранах й бактеріальних уражень органів сечостатевої системи тощо. Серед протипоказань зазначається те, що не застосовується собакам дрібних та середніх порід до 12-місячного віку, а великих порід - до 18-місячного. Не застосовують також котам до 8 місяців. Не рекомендують вагітним сукам та в період лактації й поросним свиноматкам. Сумісне застосування енрофлоксацину з тетрациклінами, макролідами (еритроміцином), хлорамфеніколом й теофіліном заборонене. Щодо продуктивних тварин, необхідно пам'ятати, що споживання молока дозволяється лише через 7 діб після останнього застосування препарату і через 14 діб - забій тварин на м'ясо. До зазначених термінів дані продукти утилізують або згодовують непродуктивним тваринам 3 урахуванням висновку лікаря ветеринарної медицини. Розчин для перорального застосування «Авітрил», цього ж виробника, рекомендують для телят, ягнят, козенят віком до 3-х місяців та свиней із бронхопневмонією, пневмонією, ентеритом, колібактеріозом, сальмонельозом, мікоплазмозом, а кролям - при бактеріальних патологіях органів травної та дихальної систем; собакам і котам - за ранових інфекцій, інфекцій зовнішнього слухового проходу, захворюваннях травного каналу, органів дихання та сечостатевої системи; лікування птиці з використанням препарату «Авітрил» проводять за мікоплазмозу, хронічних респіраторних інфекцій, колібацильозу, пастерельозу, сальмонельозу, стафілококозу й капмілобактеріозу. Щодо протипоказань у дрібних тварин (собаки і коти), то вони такі ж як і при застосуванні «Авітрил-10». Щодо жуйних не застосовують тваринам із функціонально розвиненим передшлунком. Щодо птиці - не застосовувати курам-несучкам. Не допускається одночасне застосування Авітрилу з препаратами тетрациклінового ряду, макролідами (еритроміцином), хлорамфеніколом й теофіліном. Час каренції становить 4 доби для м'яса курчат, курей-бройлерів, індиків, кролів та 7 діб телят, ягнят, кіз і свиней. В іншому разі м'ясо утилізують чи згодовують непродуктивним тваринам. «Апса полістар» - розчин для перорального застосування (Адрес Пінталуба С.А., Іспанія) використовують для свійської птиці (племінних курей, бройлерів, індиків) iз колібацильозом, мікоплазмозом, пастерельозом, некротичним ентеритом, стафілококовою та стрептококовою інфекцією. Серед протипоказань відомо, що препарат не застосовується курам-несучкам, а також сумісно із тетрациклінами, макролідами (еритроміцином), хлорамфеніколом й теофіліном. Забій птиці після останнього введення препарату дозволяється лише через 4 доби. В іншому разі - м'ясо повинно піддаватись утилізації або згодовуватись непродуктивним тваринам. «Байтрил 5\%» (Байєр Енімал Хелс ГмбХ, Німеччина, Ветеринар - Продукт ГмбХ, Німеччина) $є$ ін'єкційним розчином для лікування телят (до 3-місячного віку) із захворюваннями органів дихання та травного каналу (пастерельоз, мікоплазмоз, колібактеріоз, колісептицемія); свиней (колісептице- 
мія, діарея, ензоотична пневмонія, мастит-метритагалактія; собак (ранові інфекції, бактеріальні ураження органів дихання, травлення та сечостатевої системи). Основними протипоказаннями $є$ заборона на застосування «Байтрил 5\%» вагітним сукам і в період лактації, а також собакам будь-якої статі у перші 12 місяців життя. Протипоказаними є одночасне застосування з макролідами, тетрациклінами, хлорамфеніколом та теофіліном. Забій тварин на м'ясо дозволяється через 7 діб, а в іншому випадку - утилізують чи згодовують непродуктивним тваринам. «Байтрил 10\%» (Байєр Енімал Хелс ГмбХ, Німеччина, Ветеринар - Продукт ГмбХ, Німеччина) - розчин для перорального застосування рекомендують для кролів при захворюваннях органів дихання та травного каналу та для курчат, курей-бройлерів й індиків із мікоплазмозом, колібактеріозом, пестерельозом, сальмонельозом, стафілококозом та кампілобактеріозом. Не рекомендується препарат до застосування курамнесучкам, із печінково-нирковою недостатністю. Одночасне застосування із тетрациклінами, макролідами, хлорамфеніколом та теофіліном, а також із препаратами, що містять катіони $\mathrm{Mg}, \mathrm{Al}, \mathrm{Ca} \epsilon$ забороненим. Забій птиці на м'ясо дозволяється через 3 доби та через 15 діб - кролів. В інших випадках продукція піддається утилізації чи згодовуванню непродуктивним тваринам. «Байтрицид-К» (ВК «КРУГ», Україна) - розчин для перорального застосування застосовують як продуктивним тваринам, так і не продуктивним: телятам до 3-місяців із бронхопневмонією, пневмонією, колібацильозом, ентеритом, омфалітом, мікоплазмозом, сальмонельозом; свиням - колібацильозом, мікоплазмозом, пастерельозом, сальмонельозом, атрофічним ринітом, метрит-мастит-агалактією, ензоотичною пневмонією; курчатам-індикам, бройлерам із хронічними респіраторними інфекціями, мікоплазмозом, колібацильозом, пастерельозом, стафілококозом, кампілобактеріозом, сальмонельозом; собакам і котам - показання й протипоказання ідентичні як для препарату «Авітрил-10». Не рекомендують до застосування курам-несучкам, вагітним та в період лактації жуйним із функціонально розвиненими передшлунками. Сумісне застосування $з$ тетрациклінами, хлорамфеніколом, макролідами (еритроміцином), теофіліном, нестероїдними протизапальними засобами не допускається. Через 12 діб допускається забій тварин на м'ясо, а в іншому разі - піддається утилізації чи згодовується непродуктивним тваринам за висновком спеціаліста. «Біофлок» (ПП фірма «Фарматон», Україна) - ін'єкційний розчин, що рекомендується для ВРХ із колідіареєю, колісептицемією, пастерельозом, сальмонельозом, мікоплазмозом, стафілококозом; свиням - пастерельозом, бактеріальною пневмонією, колісептицемією, ензоотичною пневмонією, сальмонельозом, атрофічним ринітом, маститом. Серед протипоказань зазначається, що препарат не рекомендується поросним свиноматкам і в період лактації. Не сумісний лікарський препарат із макролідами, левоміцетином, тетрацикліном, теофіліном, нестероїдними протизапальними засобами. Забій тварин на м'ясо дозволяється через 14 діб, а використання молока в харчових цілях - через 4 доби. В ін- шому випадку продукція піддається утилізації чи згодовується непродуктивним тваринам. «Біофлок 0,05\%»- супозиторії для внутрішньоматкового застосування (ПП фірма «Фарматон», Україна) коровам, кобилам, козам, вівцям при післяродових внутрішньоматкових інфекціях, гострих і хронічних ендометритах, затримці посліду та післяродових ускладненнях. Одночасно не допускається застосовувати із тетрациклінами, макролідами, левоміцетином, теофіліном та стероїдними засобами. Через 3 доби допускається забій тварин на м'ясо та вживання молока. Ін'єкційний розчин «Біофлок 5\%» (ПП фірма «Фарматон», Україна) рекомендують для продуктивних, хутрових та дрібних домашніх тварин (ВРХ, ДРХ, свиней, норок, лисиць, песців, собак й котів) при: септицемії, колібактеріозі, мікоплазмозі, пастерельозі, сальмонельозі, ентериті, гастриті, атрофічному риніті, хронічному синуситі, бронхіті, пневмонії, пієлонефриті, нефриті, уретриті, уроциститі, метриті, маститі, мастит-метрит-агалактії, отиті, виразках, абсцесах, інфікованих ранах. Застереження щодо собак і котів такі ж, як при застосуванні «Авітрил-10». Заборонено також застосувати вагітним тваринам і лактуючим. Щодо сумісності 3 препаратами інших груп (див. «Біофлок 0,05\%»). Час каренції щодо застосування м'яса і молока (див. Біофлок). «Біофлок» - гель (ПП фірма «Фарматон», Україна) - гель для перорального застосування телятам до 6 місяців та поросятам віком до 4-х із: колібактеріозом, сальмонельозом, мікоплазмозом, атрофічним ринітом, ензоотичною пневмоні$є ю$, бронхопневмонією, ентеритом тощо. Сумісність 3 препаратами інших груп (див. «Байтрил 10\%»). Забій тварин на м'ясо допускається через 14 діб, а в іншому випадку - утилізація або згодовування непродуктивним тваринам з врахуванням висновку експерта. Серед препаратів, що містять енрофлоксацин відомі: «Ветофлок 5\%» (Генера Інк., Хорватія), «Енро - 10\%» (ПрАТ «Технолог», Україна), «Енродев 5\%» (ПП «Біофарм», Україна), «Енрозим 20\%», «Кілоксацин 10\%», «Мегатрил 10\%», «Медіквінол 20\%», «Віл флокс» (Туреччина), «Енроксан - 50», «Енроксан 100», «Енроксан макс», (ТОВ «БІОТЕСТЛАБ», Україна; КРКА, д.д., Ново место, Словенія), «Енроксил $5 \%$ \%, «Енроксил 10\%», «Енроксил» у формі таблеток по 15, 50, 150 мг зі смаком м'яса (КРКА, д.д., Ново место, Словенія), «Енрол 10\%» (ТОВ «АТ» Біофарм, Україна), «Енромік 5\%», «Енромік 10\%», «Енромік 20\%» (Лабораторіо Центровет Лтд, Чилі), «Енросол 10\%» (КАЛ'Я, Франція), «Енротил 20\%», «Супер енротрил 20\%» (ЮНІВЕТ, Сирія), «Енрофлоквет 10\%», «Енрофлоквет 20\%» (ТОВ «Ветсинтез», Україна), «Енрофлокс 5\%», «Енрофлокс 10\%» (Індустріал ветерінарія, Іспанія), «Енрофлоксацин 10\%» у формі розчину для ін'єкції й орального (ТзОВ УПВКФ «ВЕТЛОН», Україна), «Енрофлоксацин 50», «Енрофлоксацин 100» для ін'єкцій і орального застосування, (ТОВ фірма «Продукт», Україна), «Енрофлоксацин 10\%» оральний (ТОВ «НВП»СУЛА-ФАРМ», Україна), «Енрофлоксацин-к 5\%» для ін'єкції, «Енрофлоксацин-к 10\%» для орального введення (ПрАТ «ВНП «Укрзооветпромпостач», Україна), «Інтерфлокс» (Інтерхемі веркен «Де Аделаар» Естмі АС, Естонія), 
«Конфлокс» (Індія), «Норфлокс гель 0,5\%», «Норфлокс 5\%», «Норфлокс 10\%» (приватне підприємство «O.L.KAR-АгрозооВет-Сервіс», Україна), «Роксацин», «Сіваквінол 10\%», «Сіваквінол 100\%» відповідно (ЛАБОРАТОРІОС КАЛІСР, С.А., Іспанія; Лабораторіос Сіва). Із діючою речовиною марбофлоксацин використовують: «Марбоцил 2\%» (Ветоквінол Біовет Сп. 3 о.о., Польща), «Бофлокс» (Індустріал Ветеринаpia С.А., Іспанія), «Марбокан» (ТОВ «Ветсинтез», Україна), «Марбокс» (Сева Санте Анімаль, Франція), «Марфлоксацин» у формі таблеток по 5, 20, 80 мг, «Маркофлоксацин» та «Марфлоксин» як ін'єкційні розчини (КРКА, д.д., Ново место, Словенія). Із діючою речовиною данофлоксацин застосовують: «Данофлокс» (ПАТ «Галичфарм», Україна), «Даномед» (Туреччина), «Даноксан-50», «Даноксан-25» (ТОВ «БІОТЕСТЛАБ», Україна). «Верафлокс» містить прадофлоксацин (Байер Енімал Хелз ГмбХ, Німеччина) (Padejskaja, 2000; Kotsiumbas, 2017).

\section{Висновки}

Аналіз зареєстрованих протимікробних засобів, зокрема групи флуорхінолону, щодо їхнього раціонального використання у ветеринарній медицині забезпечує мінімізацію виникнення резистентних штамів й знижує ризики негативного впливу на здоров'я людей. Тому подальше вивчення питання «Антибіотики у ветеринарній медицині» залишається актуальним.

\section{References}

Albrecht, R. (1977). Development of antibacterial agents of the nalidixis acid type. Progress in Drug Research. 21, 9-104. https://link.springer.com/chapter/10.1007/9783-0348-7098-6_1.

Asahiu, Y., \& Ishizizak, T. (1992). Recent advances in structure activity relationships in new quinolones. Progress in Drug Research. 38, 57-106. https://www.ncbi.nlm.nih.gov/pubmed/1609118.

Beco, L., Guaguere, E., Lorente Mendez, C., Noli, C., Nuttall, T., \& Vroom, M. (2013). Suggested guidelines for using systemic antimicrobials in bacterial skin infections: part 2 - antimicrobial choice, treatment regimens and compliance. Veterinary Record. 172(6), 156-160. doi: 10.1136/vr.101070.

Blatun, L.A., Grishina, I.A., \& Svetuhin, A.M. (1994). Primenenie novogo preparata iz gruppy ftorhinolonov - lomefloksacina (masavina) pri lechenii bol'nyh s ranevoj infekciej. Antibiotiki i himiote-rapija. 39(4), 37-39 (in Russian).

Bogomolov, N.S. (1995). Desjatiletnij opit primenenija ofloksacina v rekonstruktivnoj hirurgii. Ftorhinolony: sovremennoe znachenie $\mathrm{v}$ antibakterial'noj terapii, perspektiva razvitija. Bioinform, 17-19 (in Russian).

Brighty, K.E., \& Gootz, T.D. (2000). Chemistry and Mechanism of Action of the Quinolone Antibacterials. The Quinolones 33-97. 10.1016/B978-0120595174/50003-9.
Bush, V., Dal'hovej, A., \& Cajler, H.J. (1993). Nastojashhee i budushhe hinolonov. Obzor literatury. Antibiotiki i himioterapija. 38(2-3), 3-8 (in Russian).

Cross, J.T. (2001). Fluoroquinolones. Seminars in Pediatric Infectious Diseases. 12(3), 211-223. 10.1053/spid.2001.24096

Fadeeva, N.I., Shul'gina, M.V., \& Glushkov, R.G. (1993). Molekuljarno-biologicheskie osobennosti antibakterial'nogo dejstvija proizvodnyh 4-hinolon-3karbonovoj kisloty. Obzor. lit. Himikofarmacevticheskij zhurn. 5, 5-19 (in Russian).

Khmelnytskyi, H.O., \& Dukhnytskyi, V.B. (2017). Veterynarna farmakolohiia: pidruchnyk. Kyiv (in Ukrainian).

Kosenko, M.V., Muzyka, M.V., Pashkovska, O.Z., \& Baloian, O.Z. (2000). Deiaki aspekty zastosuvannia ftorkhinoloniv $\mathrm{v}$ medychnii ta veterynarnii praktytsi. Nauk. Visn. Lvivskoi derzh. akad. veterynarnoi medytsyny im. S.Z. Hzhytskoho. 2(1), 90-92 (in Ukrainian).

Kotsiumbas, I.Ia. (2017). Veterynarni likarski zasoby Dovidnyk. Lviv: TzOV «VF» Afisha» (in Ukrainian).

Lode, H., Hoffken, G., Bolcke, M., Deppermann, N., Borner, K., \& Koeppe, P. (1990). Quinolone pharmacokinetics and metabolism. Journal of Antimicrobial Chemotherapy. 26, 41-49. https://www.ncbi.nlm.nih.gov/pubmed/2124212.

Lode, H., Hoffken, G., Borner, K., \& Koeppe, P. (1989). Unique aspects of quinolone pharmacokinetics. Clin. Pharmacokinetics. 16(1), 1-4. https://link.springer.com/ article/10.2165/00003088-198900161-00003.

Maslanka, T. (2014). Farmakologia kliniczna malych zwierzat. Olsztyn.

Padejskaja, E.N. (2000). Artrotoksichnost' kinolonov i ftorhinolonov $\mathrm{v}$ eksperimente: harakter porazhenij $\mathrm{i}$ vozmozhnyj mehanizm dejstvija. Antibiotiki i himioterapija. 45(8), 36-41 (in Russian).

Padejskaja, E.N., \& Jakovlev, V.P. (1995). Ftorhinolony. M.: Bioinform (in Russian).

Padejskaja, E.N., \& Jakovlev, V.P. (1996). Ofloksacin. Antibakterial'nyj preparat iz grup ftorhinolonov. M. (in Russian).

Piddock, L.J., Hall, M.C., \& Wise, R. (1990). Mechanizm of action of lomefloxacin. Antimicrob Agents Chemother. 34(6), 1088-1093. https://www.ncbi.nlm. nih.gov/pmc/articles/PMC171763.

Slobodiuk, N.M. (2003). Vyznachennia toksychnosti ofloksatsynu pry sumisnomu zastosuvanni $\mathrm{Z}$ dymeksydom. IV nauk. prakt. konf. Problemy neinfektsiinoi patolohii tvaryn. Bila Tserkva, 76-78 (in Ukrainian).

Smith, J.T. (1986). Mechanism of action of quinolones. Infection. 14(1), 3-15. https://www.ncbi.nlm.nih.gov/ pubmed/2420724.

Swarz, M.N. (1997). Use antimicrobial agents and drag resistance. The New England Journal of Medicine. 337, 491-492. doi: 10.1056/NEJM199708143370709.

Walker, R.C., \& Wright, A.J. (1991). The fluoroquinolones. Mayo Clinic Proceedings. 66(12), 1249-1259. https://www.ncbi.nlm.nih.gov/pubmed/1749294. 